\title{
Influence of Lysozyme Addition on Hydroxycinnamic Acids and Volatile Phenols during Wine Fermentation
}

\author{
Stephan Sommer ${ }^{1, *(\mathbb{D})}$, Pascal Wegmann-Herr ${ }^{2}$, Michael Wacker ${ }^{2}$ and Ulrich Fischer ${ }^{2}$ \\ 1 Appalachian State University, Fermentation Sciences, 730 Rivers St., Boone, NC 28608, USA \\ 2 Institute for Viticulture and Enology (DLR-Rheinpfalz), Breitenweg 71, 67435 Neustadt, Germany; \\ pascal.wegmann-herr@dlr.rlp.de (P.W.-H.); michael.wacker@dlr.rlp.de (M.W.); ulrich.fischer@dlr.rlp.de (U.F.) \\ * Correspondence: sommers@appstate.edu; Tel.: +1-828-262-8136
}

Received: 10 December 2017; Accepted: 19 January 2018; Published: 21 January 2018

\begin{abstract}
Most yeast and bacteria in wine are able to metabolize hydroxycinnamic acids into volatile phenols via enzyme-mediated decarboxylation. Our trials performed in wine and model systems suggest that lysozyme addition prior to fermentation affects both bacterial activity and the release of hydroxycinnamic acids from their tartrate esters. This increases the potential for volatile phenol formation, as microorganisms can only metabolize free hydroxycinnamates. Wines with delayed malolactic fermentation due to lysozyme addition contained significantly higher concentrations of free hydroxycinnamic acids and elevated levels of volatile phenols in some cases. The reason for this is likely related to the side activity of lysozyme in combination with a detoxification mechanism that only occurs under stressful conditions for the yeast. Experiments in model systems indicate that lysozyme can affect the yeast at a $\mathrm{pH}$ higher than usually found in wine by attacking chitin in the bud scars of the cell walls and therefore weakening the cell structure. Free hydroxycinnamates can also affect yeast viability, making an increased release during fermentation problematic for a successful fermentation.
\end{abstract}

Keywords: lysozyme; Saccharomyces; volatile phenols; hydroxycinnamic acids

\section{Introduction}

Fresh and acid-driven white wines are commonly produced without intentional bacterial activity. Traditional ways to prevent bacterial growth are stabilization with sulfur dioxide $\left(\mathrm{SO}_{2}\right)$, pasteurization at $60{ }^{\circ} \mathrm{C}$ for two minutes [1], or lysozyme addition. Lysozyme is a $1,4-\beta-N$-acetyl-muramidase, which cleaves the $\beta$ 1,4-glycosidic bonds between $N$-acetyl-muramic acid and peptido-glycans in cell walls of Gram-positive bacteria [2]. Commercial lysozyme is a white slightly sweet powder that is purified from egg-white and was approved for wine treatment by the International Organisation of Vine and Wine in 2001 with a maximum legal limit of $0.5 \mathrm{~g} / \mathrm{L}$ wine [3,4]. In contrast to sulfur dioxide, the efficiency of lysozyme increases with increasing $\mathrm{pH}$ [5], with an effective $\mathrm{pH}$ range from 3.5 to 12.0 [6] which makes it usable in all types and styles of wine. Malo-lactic fermentation (MLF) can be delayed by the addition of $250 \mathrm{mg} / \mathrm{L}$ and a treatment with $500 \mathrm{mg} / \mathrm{L}$ generally prevents any bacterial activity. The inhibiting effect of $500 \mathrm{mg} / \mathrm{L}$ lysozyme is comparable to the addition of $40 \mathrm{mg} / \mathrm{L} \mathrm{SO}_{2}$ [5]. Saccharomyces yeast is not reported to be influenced by lysozyme under winemaking conditions.

The phenolic composition of wine is complex, but the amount of hydroxycinnamic acid (HCA) usually varies between 100 and $200 \mathrm{mg} / \mathrm{L}$, depending on the grape variety and winemaking process [7-9]. According to Suarez et al. (2007), most yeast and bacteria species in wine are able to metabolize hydroxycinnamic acids under winemaking conditions to form vinylphenols. However, further reduction of vinylphenols to ethylphenols can only be conducted by a few yeasts such as Dekkera/Brettanomyces, or Pichia. Lactic acid bacteria or Saccharomyces yeast strains form little or no ethylphenols [10]. 
The predominant volatile phenols in wine are 4-vinylguaiacol, 4-vinylphenol, 4-ethylguaiacol, and 4-ethylphenol [11]. The formation during fermentation depends on the yeast strain and the concentration of phenolic inhibitors [12]. White wines are dominated by vinylphenols, while red wines mostly contain ethylphenols [13]. The corresponding enzyme for the decarboxylation of HCA is located in the yeast cell cytoplasm with a $\mathrm{pH}$ optimum of 6.5 , which infers that this process is only active in living cells. The conversion rate is strain specific; although all strains appear to incorporate hydroxycinnamic acids, only some metabolize them into volatile phenols. A higher concentration of precursors does not necessarily correspond to increased enzyme activity, which peaks at the beginning of the stationary phase and remains at that level until cell death is induced [12]. Commercial strains might possess this decarboxylase activity but can only metabolize the free acid form and not the tartaric ester, which is the predominant form in the grape [14]. According to Grando et al. [15], vinylphenols are an indicator for yeast activity, although there is no proof that yeast is actively regulating the conversion.

The objective of this study was to explain our previous observation that wines treated with lysozyme may display elevated levels of free hydroxycinnamic acids and, in some cases, volatile phenols and investigate this phenomenon using a model system.

\section{Materials and Methods}

\subsection{Must Media Fermentations}

Preliminary experiments were conducted in grape must and wine under varying winemaking conditions. Trials were done in Vitis vinifera L. cv. Chardonnay and Pinot blanc in 2008 and 2009. Naturally occurring Botrytis cinerea was used to evaluate the effect of mold infections on HCA concentration. Infected grapes were treated separately and blended with healthy material where applicable. All fermentations were performed in $25 \mathrm{~L}$ glass carboys. Fermentation temperature was maintained at $18{ }^{\circ} \mathrm{C}$ and all experiments were performed in duplicate. Where applicable, $100 \mathrm{mg} / \mathrm{L}$ lysozyme (Lallemand, Montréal, QC, Canada) or $50 \mathrm{mg} / \mathrm{L}$ sulfur dioxide were added to the juice prior to inoculation. If the experiment included a $\mathrm{pH}$ variation, the $\mathrm{pH}$ was adjusted with sodium hydroxide or phosphoric acid (both VWR, Radnor, PA, USA). Saccharomyces cerevisiae (CY 3079, Lalvin, Lallemand, Montréal, QC, Canada) was inoculated at a rate of $20 \mathrm{~g} / 100 \mathrm{~L}$. Malolactic fermentation (MLF) was induced with a commercial freeze-dried Oenococcus oeni culture (Enoferm ${ }^{\circledR}$ ALPHA, Lallemand; AWRI culture collection B421) where applicable. All organisms were used following the instructions of the manufacturer. MLF was either induced as mentioned above or was conducted spontaneously with native bacteria. Selected experiments were also performed with native yeast for alcoholic fermentation (AF) and native bacteria for MLF. The objective was to evaluate the effect of microbial interaction on general fermentation behavior and volatile phenol production.

Grapes were crushed, pressed, and cold settled over night prior to fermentation. Initial juice analysis was performed via FT-MIR spectroscopy (FT 120 WineScan, FOSS, Hillerød, Denmark) and is shown in Table 1.

Table 1. Analytical data of grape musts prior to fermentation.

\begin{tabular}{cccccc}
\hline Cultivar & $\begin{array}{c}\text { Total Sugar } \\
(\mathbf{g} / \mathrm{L})\end{array}$ & $\begin{array}{c}\text { Titratable } \\
\text { Acid (g/L) }\end{array}$ & $\mathbf{p H}$ & $\begin{array}{c}\text { Amino-Nitrogen } \\
\text { (NOPA) }(\mathbf{m g} / \mathrm{L})\end{array}$ & $\begin{array}{c}\text { Ammonium } \\
(\mathbf{m g} / \mathrm{L})\end{array}$ \\
\hline 2008 Chardonnay & 209.1 & 8.3 & 3.5 & 147 & 94 \\
2009 Chardonnay & 229.1 & 7.2 & 3.5 & 168 & 38 \\
2008 Pinot blanc & 200.2 & 7.0 & 3.4 & 210 & 108 \\
2009 Pinot blanc & 203.4 & 6.5 & 3.6 & 227 & 62 \\
\hline
\end{tabular}

Fermentation performance and yeast-related parameters (fermentable sugar, total acid, ethanol, and $\alpha$ amino acids) were monitored using FT-MIR. Samples for fermentation control were taken daily. 
The finished wines were stabilized with $100 \mathrm{mg} / \mathrm{L}$ sulfur dioxide, filtered through K100 cellulose filter pads (Seitz Pall, Port Washington, NY, USA), and bottled prior to final analysis.

Table 2 summarizes the experiments that were performed with grapes.

Table 2. Analytical data of grape musts prior to fermentation.

\begin{tabular}{|c|c|c|}
\hline \multirow{2}{*}{ Pinot Blanc 0\% Botrytis cinerea Infection } & pH 3.4 & $\begin{array}{c}\mathrm{No} \mathrm{SO}_{2} \\
50 \mathrm{mg} / \mathrm{L} \mathrm{SO}_{2} \\
100 \mathrm{mg} / \mathrm{L} \text { lysozyme }\end{array}$ \\
\hline & pH 3.6 & $\begin{array}{c}\mathrm{No} \mathrm{SO}_{2} \\
50 \mathrm{mg} / \mathrm{L} \mathrm{SO}_{2} \\
100 \mathrm{mg} / \mathrm{L} \text { lysozyme }\end{array}$ \\
\hline \multirow{2}{*}{ Pinot Blanc $50 \%$ Botrytis cinerea Infection } & pH 3.4 & $\begin{array}{c}\mathrm{No} \mathrm{SO}_{2} \\
50 \mathrm{mg} / \mathrm{L} \mathrm{SO}_{2} \\
100 \mathrm{mg} / \mathrm{L} \text { lysozyme }\end{array}$ \\
\hline & pH 3.6 & $\begin{array}{c}\mathrm{No} \mathrm{SO}_{2} \\
50 \mathrm{mg} / \mathrm{L} \mathrm{SO}_{2} \\
100 \mathrm{mg} / \mathrm{L} \text { lysozyme }\end{array}$ \\
\hline Chardonnay & pH 3.5 & $\begin{array}{c}100 \mathrm{mg} / \mathrm{L} \text { lysozyme } \\
\text { Spontaneous MLF } \\
\text { Simultaneous MLF } \\
\text { Sequential MLF } \\
\text { Spontaneous fermentation }\end{array}$ \\
\hline
\end{tabular}

\subsection{Synthetic Media Fermentations}

Bench-scale fermentation experiments were conducted in YPD-medium (Sigma-Aldrich, St. Louis, MO, USA) using the same wine yeast as trials conducted in grape must. Phosphoric acid and sodium hydroxide were used to adjust the $\mathrm{pH}$ to (1) $\mathrm{pH} 3.0$ to mimic harsh wine conditions and (2) $\mathrm{pH} 6.6$ to account for the $\mathrm{pH}$ optimum of the decarboxylase enzyme to maximize volatile phenol production while minimizing stress for the yeast. Fermentations were monitored over ten days.

For the organism-free storage trials with lysozyme, an acetate buffer containing $6.0 \mathrm{~g} / \mathrm{L}$ acetic acid and $8.2 \mathrm{~g} / \mathrm{L}$ sodium acetate (all VWR International, Radnor, PA, USA) at pH 4.7 was prepared. This $\mathrm{pH}$ range is commonly used for enzyme-activity assessment, since it maximizes transformation rates [16]. Lysozyme (Lysovin, Scott Laboratories, Pickering, ON, Canada) was added to the buffer at $200 \mathrm{mg} / \mathrm{L}$ in addition to $500 \mathrm{mg} / \mathrm{L}$ dibutyl tartrate (Acros Organics, NJ, USA). Storage trials were conducted over 120 days and free tartrate was analyzed spectrophotometrically with sodium metavanadate (Sigma Aldrich, St. Louis, MO, USA) according to Rebelein [17] with minor modifications suggested by Fernandes and Reis [18].

\subsection{Hydroxycinnamic Acid Analysis by LC-DAD}

The analysis of hydroxycinnamic acids (HCA) by HPLC-DAD was adapted from Rentzsch et al. [19]. Quantitative analysis of HCAs at $320 \mathrm{~nm}$ was shown to have no interferences from other phenols or tannins from seeds and skins [20]. Identification of peaks was performed using analytical standards and UV-Vis spectral data [21,22]. The LC instrument consisted of a Jasco PU 980 low pressure gradient pump and the 3-line degasser Spectra Systems SCM 1000 coupled with a Jasco MD 2010 Plus, Diode Array Multiwavelength Detector (Jasco Germany GmbH, Gross-Umstadt, Germany). Samples were injected by a Spark Basic Marathon autosampler (Spark Holland B.V., Emmen, Netherlands) on a YMC-Pack ODS-AM separation column with the dimensions $250 \mathrm{~mm} \times 4.6 \mathrm{~mm}$ and a particle size of $5 \mu \mathrm{m}$ (YMC Europe $\mathrm{GmbH}$, Dinslaken, Germany). The oven temperature was set to $50{ }^{\circ} \mathrm{C}$. A binary gradient at a constant flow of $0.5 \mathrm{~mL} / \mathrm{min}$ was used with eluent $\mathrm{A}$ being water with $5 \%$ acetonitrile and a $10 \mathrm{mM} \mathrm{KH} \mathrm{PO}_{4} / \mathrm{H}_{3} \mathrm{PO}_{4}$ buffer and eluent B being a 50:50 acetonitrile-water mixture with a $10 \mathrm{mM}$ $\mathrm{KH}_{2} \mathrm{PO}_{4} / \mathrm{H}_{3} \mathrm{PO}_{4}$ buffer. Conditions started at $85 \%$ eluent A decreased to $80 \%$ by 15 min, from $80 \%$ to 
$65 \%$ by $40 \mathrm{~min}$, and from $65 \%$ to $45 \%$ by $45 \mathrm{~min}$. After $50 \mathrm{~min}$, it was then set back to initial conditions ( $85 \%$ A) for $10 \mathrm{~min}$ to reach equilibrium (total analysis time $60 \mathrm{~min}$ ).

Instrument control and data acquisition were performed with Chrompass Version 1.8 (Jasco Corporation, Gross-Umstadt, Germany). Most tartrate esters of hydroxycannamic acids are not commercially available [23], therefore the quantification was done as suggested in the literature by calculating concentrations as monomeric HCA equivalents [24]. HCAs were quantified as $p$-coumaric acid and ferulic acid equivalents (standards purchased from Sigma-Aldrich, St. Louis, MO, USA).

\subsection{Volatile Phenol Analysis by GC-MS}

Volatile phenols were first extracted by solid phase extraction (Lichrolut EN 200 mg, Merck KGaA, Darmstadt, Germany), eluted with dichloromethane, and analyzed by GC-MS. $\left[{ }^{2} \mathrm{H}_{2}\right]$-4-ethylphenol and 3,4 dimethylphenol were used as internal standards (500 $\mu \mathrm{g} / \mathrm{L}$ prior to solid phase extraction).

The GC-MS setup that was used was a Thermo Trace GCxGC (Thermo Fisher Scientific, Dreieich, Germany), with a split/splitless injector in connection with a Finnigan Trace DSQ (Thermo Fisher Scientific, Dreieich, Germany). An amount of $2 \mu \mathrm{L}$ of sample was injected splitless under a surge pressure of $150 \mathrm{kPa}$ for 2 min using a TriPlus AS autosampler (Thermo Fisher Scientific, Dreieich, Germany). The injector port was held at a temperature of $230{ }^{\circ} \mathrm{C}$. The separation column was a $20 \mathrm{~m} \times 0.18 \mathrm{~mm}$ i.d. fused silica capillary column, coated with $0.32 \mu \mathrm{m}$ of a $5 \%$ phenyl $95 \%$ dimethylpolysiloxane stationary phase (ZB-5, Phenomenex, Aschaffenburg, Germany). The inlet pressure was held at a constant pressure of $102 \mathrm{kPa}$ with helium as a carrier gas. The temperature profile was started at $40^{\circ} \mathrm{C}$, initially held for $4 \mathrm{~min}$ and then raised to $180^{\circ} \mathrm{C}$ with a rate of $3^{\circ} \mathrm{C} / \mathrm{min}$. It was held for $0.5 \mathrm{~min}$ and raised to $300{ }^{\circ} \mathrm{C}$ with a rate of $6{ }^{\circ} \mathrm{C} / \mathrm{min}$. That final temperature was held for $5 \mathrm{~min}$ to prepare for the next run. The MS transfer line and ion source temperature were held at $250^{\circ} \mathrm{C}$. Electronic ionization was realized at $70 \mathrm{eV}$. Detection (EI+) was in the full scan mode $(m / z$ 29-161) and quantification was done on extracted ion traces of fragment ions (4-ethylphenol: $m / z$ 77, 107, 122; 4-vinylphenol: $m / z$ 91, 120; 4-ethylguaiacol: $m / z$ 137, 152; 4-vinylguaiacol: $m / z$ 77, $107,135,150)$. Instrument control and data acquisition were performed with Xcalibur (Version 1.2; ThermoFisher Scientific, Waltham, MA, USA).

\subsection{Flow Cytometry}

The analysis of yeast cell viability and bud-scar fluorescence was performed by flow cytometry using a CyFlow Cube 6 instrument (Sysmex Partec, Görlitz, Germany) equipped with a 488-nm laser. Fluorescein diacetate and propidium iodide (both Sigma Aldrich, St. Louis, MO, USA) were used for viability with a protocol published by Hutter [25]. A wheat germ agglutinin-fluorescein isothiocyanate conjugate (Sigma Aldrich, St. Louis, MO, USA) was used for bud-scar analysis as described by Hutter and Nitzsche [26].

\subsection{Data Analysis}

Data handling and statistical analyses were done with the Excel Statistics Add-on XL-Stat 2010 (Addinsoft Deutschland, Andernach, Germany) and SigmaPlot 12.5 (Systat Software Inc., San Jose, CA, USA).

\section{Results and Discussion}

Previous studies suggest that a delay in malolactic fermentation can lead to elevated levels of volatile phenols [27]; the reason for that phenomenon is currently unknown. The malic acid degradation in Chardonnay and Pinot blanc shown in Figure 1 confirms that lysozyme can delay but not inhibit MLF if it is added in concentrations below the legal limit. Since results obtained in 2009 were very similar to those in 2008, they were used as confirmation data and are not presented separately here. 


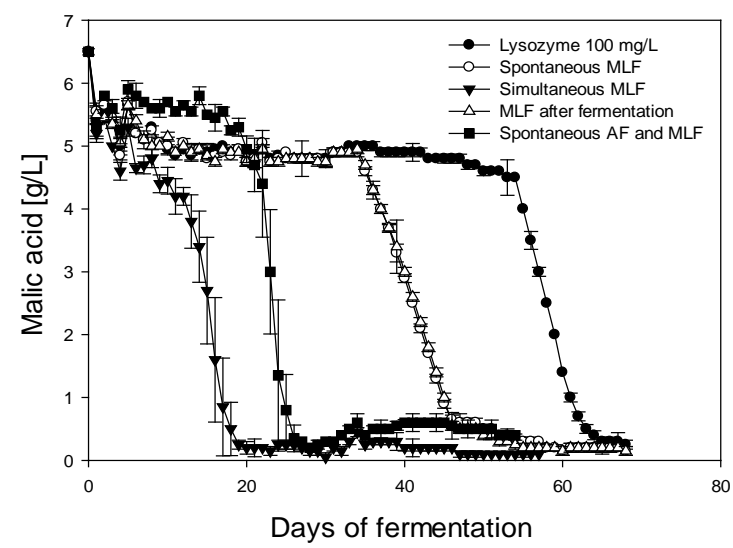

(a)

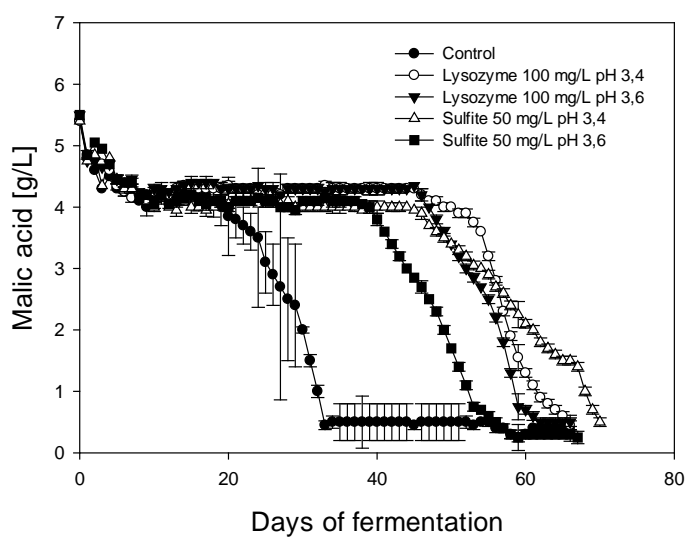

(b)

Figure 1. Delayed malolactic fermentation due to the addition of lysozyme in Chardonnay (a) and Pinot blanc (b) analyzed by FT-MIR spectroscopy (AF: alcoholic fermentation, MLF: malolactic fermentation) Error bars represent the standard deviation of experimental duplicates.

The addition of $100 \mathrm{mg} / \mathrm{L}$ lysozyme in 2008 was only sufficient to delay MLF for about 50 days, after which malate degradation could be observed and was essentially complete in a time-span comparable to the control. It remains unclear whether the lysozyme was degraded, bound, precipitated, or somehow metabolized but a clear loss in activity is evident over time as reported in other studies $[4,28]$.

It is suggested that lysozyme can bind to polyphenols, which leads to the inactivation of the enzyme. These processes may occur in the first few days of fermentation. As previously described, the effect of lysozyme additions is comparable to low sulfur dioxide additions [5], which could also be confirmed here by the direct comparison between the two treatments (Figure 1b). In this case, $50 \mathrm{mg} / \mathrm{L}$ $\mathrm{SO}_{2}$ had the same effect as $100 \mathrm{mg} / \mathrm{L}$ lysozyme. General yeast performance and the yield of alcoholic fermentation in this study was not influenced by lysozyme. Since $\mathrm{pH}$ influences the efficiency of sulfur dioxide, the lower $\mathrm{pH}$ shown in Figure $1 \mathrm{~b}$ displays a longer delay in MLF but seems to have no effect on lysozyme.

There are indications in the literature that lysozyme additions can modify the volatile aroma characteristics of wine even if no MLF is observed [29]. In the present study, additional observations could be made that involve the effect of lysozyme on the phenolic profile of wine, suggesting that lysozyme addition to the juice prior to fermentation may not only affect bacterial activity but also the release of hydroxycinnamic acids from their tartrate esters. This increases the theoretical potential for volatile phenol formation because microorganisms can only metabolize free hydroxycinnamates. Although general yeast performance was not affected by lysozyme, wines with delayed malolactic fermentation due to low level lysozyme addition $(100 \mathrm{mg} / \mathrm{L})$ contained significantly higher concentrations of free hydroxycinnamic acids. Figure 2 shows hydroxycinnamic acids after wine production in Pinot blanc with healthy grapes and 50\% Botrytis cinerea infected grapes, as well as in Chardonnay.

While Botrytis only has a minor effect on the concentration of $p$-coumaric acid after fermentation, ferulic acid was below the detection limit in most wines made from infected grapes. The only exceptions were wines treated with lysozyme. One explanation could be the increased activity of Botrytis cinerea's polyphenol oxidase, laccase, which is not inhibited by low levels of sulfur dioxide and could therefore reduce HCAs effectively. Previous studies suggest that Botrytis infections influence HCAs differently [30]. While ferulic acid and caffeic acid can be depleted completely, $p$-coumaric acid tends to remain stable, leading to a higher potential of 4-vinylphenol production in infected wines. It is also worth noting that an analytical decrease in HCA tartrate esters does not necessarily correspond 
to an increase in free HCAs. This can be explained by the high reactivity of these molecules and the formation of several reaction products (GRPs) [31,32].
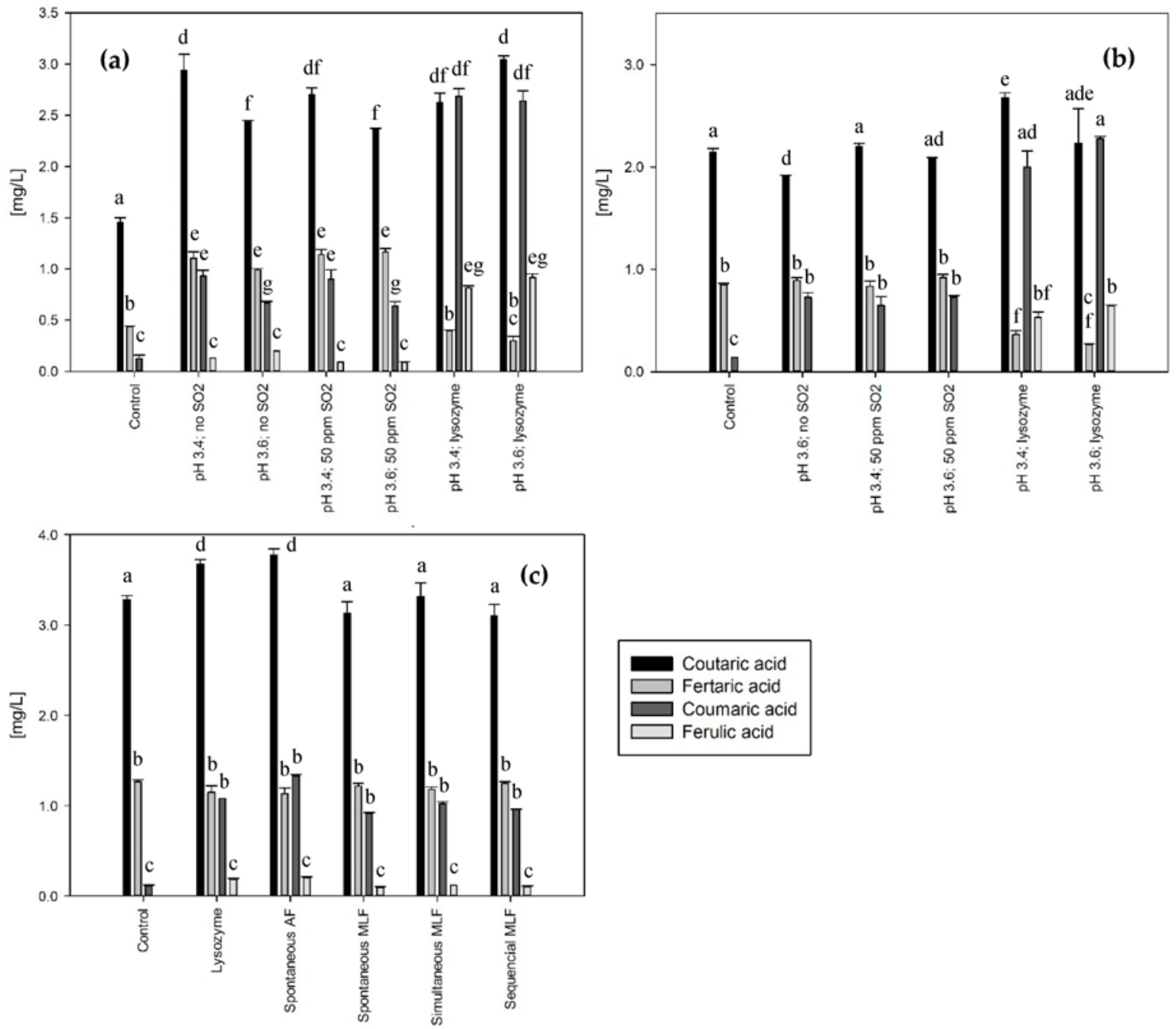

Figure 2. Hydroxycinnamic acids after winemaking in Pinot blanc with (a) healthy grapes and (b) $50 \%$ Botrytis cinerea infected grapes, as well as (c) in Chardonnay (AF: alcoholic fermentation, MLF: malolactic fermentation) vintage 2008. Letters a,b,c,d,e,f,g indicate statistically significant differences determined by ANOVA.

While the concentration of free hydroxycinnamic acids was significantly higher in Pinot blanc wines, Chardonnay treated with lysozyme prior to fermentation did not display elevated levels compared to other fermentation strategies (Figure 2). This inconsistent behavior cannot be explained by lysozyme alone but might be caused by differences in $\mathrm{pH}$, inhibiting compounds, and the availability of tartrate-bound precursors as reported by Chatonnet, Dubourdieu, Boidron and Lavigne [12]. However, when free hydroxycinnamic acids are present, the potential for volatile phenol formation increases drastically. Figure 3 shows volatile phenol levels in the corresponding Chardonnay and Pinot blanc wines. According to the literature, HCAs are metabolized to volatile phenols as long as no inhibiting substances such as tannins are present [12]. In Pinot blanc with a low concentration of phenolic substances, the decarboxylation should readily occur.

The pattern of volatile phenol production over all experiments shows a positive correlation (correlation coefficient: $0.708, p$ value: 0.009 ) with precursor concentrations shown in Figure 2. The only exception is the lysozyme-treated wine with higher $\mathrm{pH}$. Despite the high level of $p$-coumaric acid, 
the formation of the corresponding volatile phenol was not increased. Possible reasons for that were evaluated in model wines and will be discussed later.

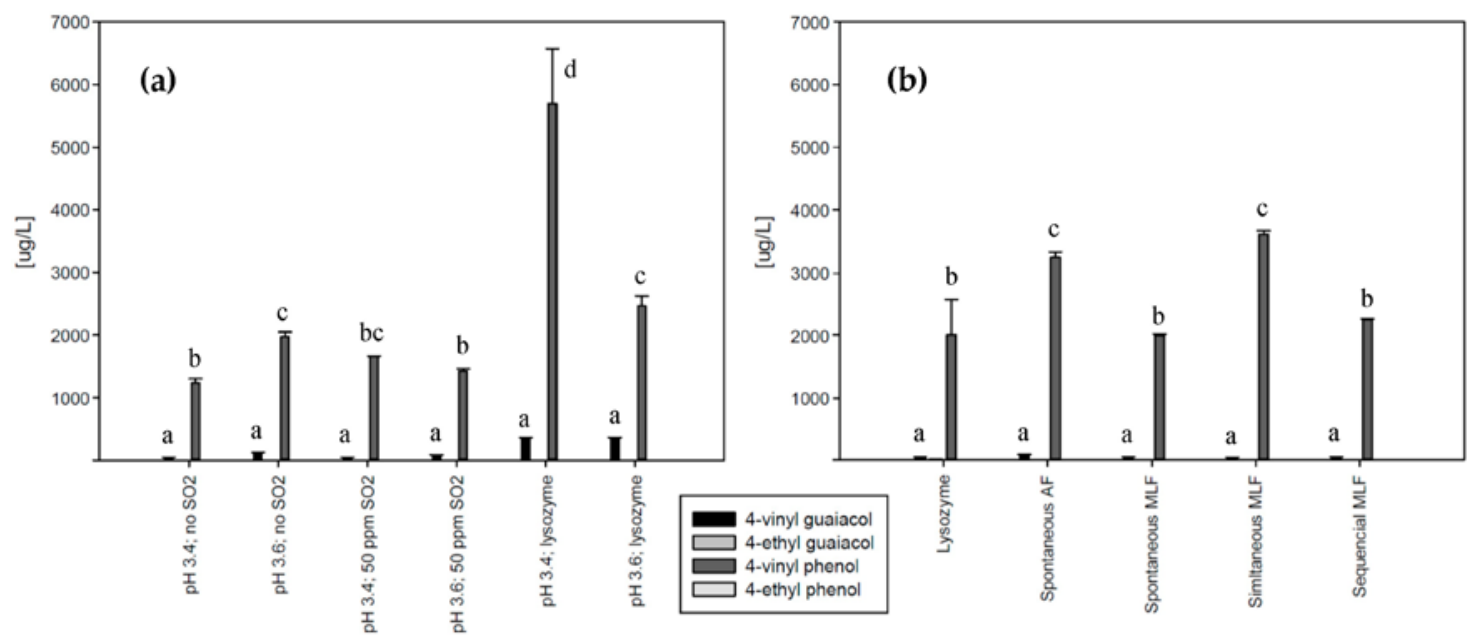

Figure 3. Volatile phenol concentration in (a) Pinot blanc and (b) Chardonnay wines (AF: alcoholic fermentation, MLF: malolactic fermentation). Letters a,b,c,d indicate statistically significant differences determined by paired $t$-test.

The transformation of hydroxycinnamic acids into volatile phenols could be a stress reaction where acids are metabolized into a less toxic form [7]. Saccharomyces cerevisiae is only able to decarboxylize the trans-(E)-configuration with a higher affinity towards $p$-coumaric acid compared to ferulic acid [12]. Our results (in Figures 2 and 3) show this higher affinity, but also illustrate the question of which factors might influence the yeast metabolism of these compounds.

It was previously observed that the concentration of monomeric hydroxycinnamates increased in the presence of lysozyme [33]. In the current study, this increase occurred after alcoholic and malolactic fermentation in the wine matrix, indicating a slow process and only passive involvement of the present organisms. Consequently, the subsequent model trials were performed under sterile conditions without organisms. Model experiments using dibutyl tartrate as a model tartrate ester revealed that lysozyme indeed has a side activity that causes these ester bonds to be cleaved (Figure 4). An inexpensive model ester, dibutyl tartrate, was used to specifically monitor the tartrate esterase activity over time. Under optimized $\mathrm{pH}$ conditions for this reaction, as suggested by Sashiwa, Saimoto, Shigemasa, Ogawa and Tokura [16], which is slightly higher than found in wine, the model ester is degraded within 120 days, which leads to a significant increase in free tartaric acid levels compared to the control.

It is well established that Gram-positive lactic acid bacteria are sensitive to lysozyme; however, it has been shown before that yeast can also be affected under certain conditions. Some molecular biological methods use the lysozyme in combination with other enzymes at $\mathrm{pH} 5$ to perforate the cell wall of yeast in order to make it accessible for fluorescent probes [34]. It is plausible that lysozyme is able to directly influence the metabolism of yeast cells since the structure of chitin in their cell walls and specifically in bud scars is structurally similar to the target molecules of Gram-positive bacteria cells. The yeast cell wall is complexed with approximately $2-4 \%$ chitin to provide stability. The chitin is mainly located in the ringed structures of bud and birth scars [35]. Even partial degradation could lead to an increasing stress level, leaky cells, and the induction of detoxification pathways.

Our experiments in model systems indicate that lysozyme can affect the yeast by attacking chitin. To clarify the role of Saccharomyces in the release of volatile phenols from increased precursor concentrations, these experiments were done in a synthetic YPD medium. While fermentation performance was not affected by HCA or lysozyme additions as high as $500 \mathrm{mg} / \mathrm{L}$, cell survival at low $\mathrm{pH}$ after fermentation was lowered significantly (Figure 5). The antimicrobial effect of HCAs on 
lactic acid bacteria through neutralizing the membrane potential and disrupting energy generation for the cell has been reported [36] but the trend can also be observed with yeast here. The number of dead cells in the presence of HCAs was significantly higher at low $\mathrm{pH}$ than the control and at a higher $\mathrm{pH}$. The effect of lysozyme on bud scar fluorescence is also clearly visible at high $\mathrm{pH}$. Increased fluorescence indicates that more chitin is exposed and can bind the dye, which is an indication that it is partially degraded. This observation supports the hypothesis that, under certain circumstances, lysozyme can play a role in the long-term survival and viability of yeast.

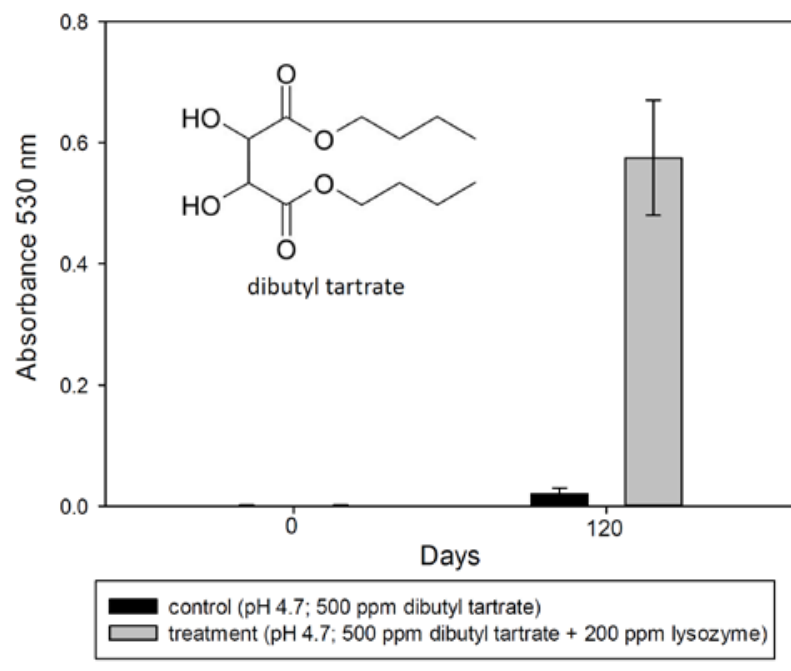

Figure 4. Free tartaric acid released from the model ester dibutyl tartrate after 120 days of storage in a model system in the presence of lysozyme without microbial activity.

HCAs may have an inhibiting effect on starving yeast cells when the ability to maintain neutral cellular $\mathrm{pH}$ is limited. Figure $5 \mathrm{~b}$ shows a significant increase in dead yeast cells at low $\mathrm{pH}$ and especially with higher levels of HCA in the medium. The cellular detoxification mechanism should lead to higher rates of decarboxylation and therefore increased levels of volatile phenols as observed in other studies [7].
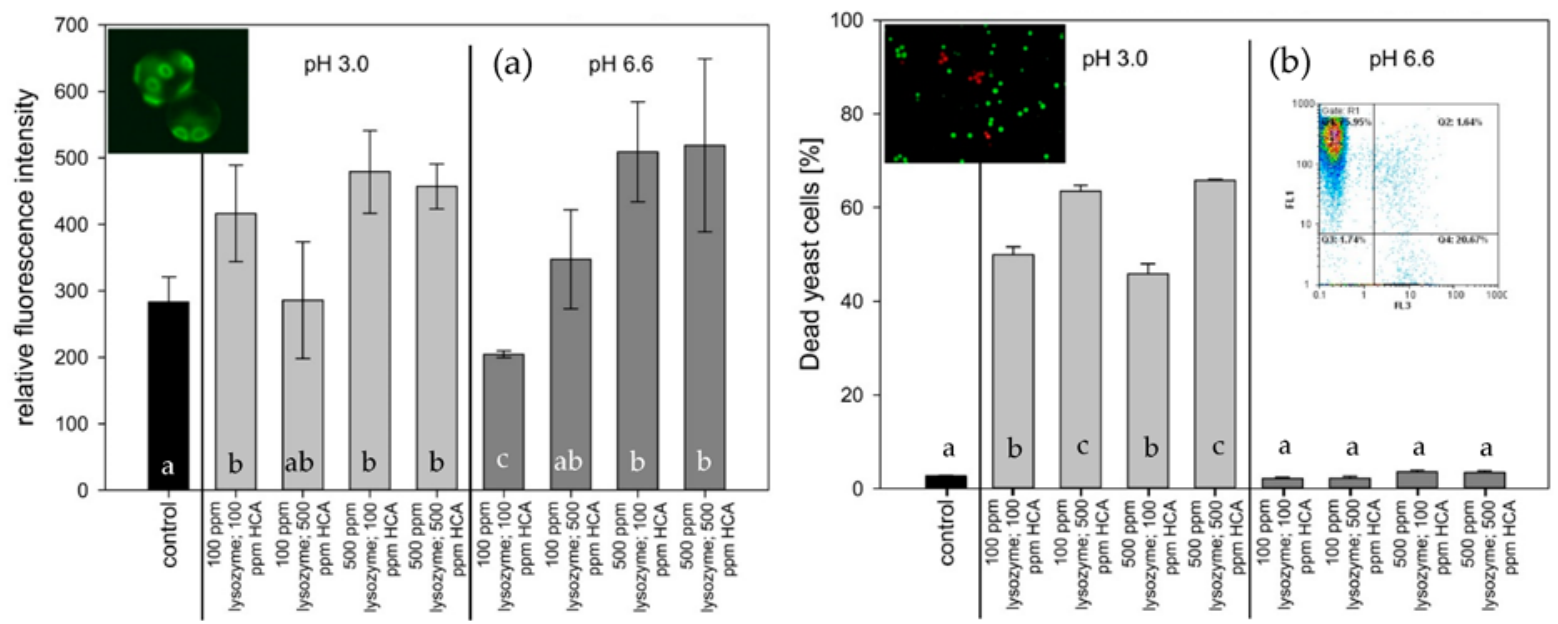

Figure 5. Model fermentations in YPD medium in the presence of lysozyme and hydroxycinnamic acids at different $\mathrm{pH}$ conditions ((a) bud scar fluorescence by flow cytometry, (b) yeast viability by flow cytometry). Letters $\mathrm{a}, \mathrm{b}, \mathrm{c}$ indicate statistically significant differences determined by paired $t$-test. 
However, this increase does not occur in all cases. In our wine experiments, only Pinot blanc at lower $\mathrm{pH}$ showed significantly higher levels of volatile phenol production with elevated precursor concentrations. On the other hand, the Chardonnay trials with larger amounts of monomeric hydroxycinnamates did not necessarily result in higher volatile phenol synthesis. Previous studies demonstrated that HCAs are passively transported into the cell easier than other phenolic acids $[12,13,37]$. With a $\mathrm{pK}_{\mathrm{A}}$ between 4.01 and 4.42 , these molecules have a predominantly neutral charge at wine $\mathrm{pH}$ and are not deprotonated. After reaching the cytoplasm through passive diffusion, the acids release a proton and lower the cellular $\mathrm{pH}$. The decarboxylase that produces volatile phenols is activated by low $\mathrm{pH}$ and the enzyme activity is generally decreasing with increasing $\mathrm{pH}$ [38]. Conversely, at higher $\mathrm{pHs}$ (i.e., $\mathrm{pH} 6.6$ in this case), HCAs are favored in their dissociated form and are therefore not transported nor decarboxylated by the yeast. Table 3 shows the decrease of $p$-coumaric acid in a model system during fermentation.

Table 3. Changes in $p$-coumaric acid at different concentrations and $\mathrm{pH}$ in model trials.

\begin{tabular}{cccc}
\hline Sample & $\begin{array}{c}\text { Initial } \boldsymbol{p} \text {-Coumaric Acid } \\
\text { Concentration }(\mathbf{m g} / \mathbf{L})\end{array}$ & $\begin{array}{c}p \text {-Coumaric Acid after } \\
\text { 10 Days (mg/L) }\end{array}$ & $\begin{array}{c}p \text {-Coumaric Acid Lost } \\
\mathbf{( \% )}\end{array}$ \\
\hline pH 3.0; 100 ppm lysozyme & 100.8 & $76.6 \pm 10.1$ & $23.4 \pm 10.1$ \\
pH 3.0; 100 ppm lysozyme & 500.7 & $401.5 \pm 13.3$ & $19.7 \pm 2.7$ \\
pH 3.0; 500 ppm lysozyme & 100.8 & $78.7 \pm 25.3$ & $21.3 \pm 25.3$ \\
pH 3.0; 500 ppm lysozyme & 500.7 & $393.6 \pm 3.2$ & $21.3 \pm 0.6$ \\
pH 6.6; 100 ppm lysozyme & 100.5 & $76.7 \pm 1.6$ & $23.3 \pm 1.6$ \\
pH 6.6; 100 ppm lysozyme & 500.9 & $438.7 \pm 20.8$ & $12.3 \pm 4.2$ \\
pH 6.6; 500 ppm lysozyme & 100.5 & $82.8 \pm 4.6$ & $17.2 \pm 4.6$ \\
pH 6.6; 500 ppm lysozyme & 500.9 & $439.1 \pm 21.9$ & $12.2 \pm 4.4$ \\
\hline
\end{tabular}

Quantitatively, some HCAs are always lost, independent from starting concentration, $\mathrm{pH}$, or lysozyme addition. However, at higher $\mathrm{pH}$, the medium seems to retain higher levels of $p$-coumaric acid, especially when concentrations are high. Campos, Couto and Hogg [36] demonstrated that $500 \mathrm{mg} / \mathrm{L}$ of HCAs can inhibit bacteria; however, yeast seems to be less affected by these unusually high levels. At low wine $\mathrm{pH}$, on the other hand, possibly in combination with other stressful medium conditions, hydroxycinnamic acids can be readily converted into volatile phenols once they are released from their precursors.

\section{Conclusions}

Our studies performed with Chardonnay and Pinot blanc fermentations in two vintages suggest that lysozyme addition to juice prior to fermentation may not only affect bacterial activity but also the release of hydroxycinnamic acids from their tartrate esters. This increases the theoretical potential for volatile phenol formation because microorganisms can only metabolize free hydroxycinnamates. In addition to that, lysozyme and HCAs in combination with unfavorable $\mathrm{pH}$ conditions were shown to have a negative effect on yeast survival after fermentation. These stress conditions around $\mathrm{pH}$ 3 are expected to result in an attempt to detoxify the medium in order to secure cell survival and consequently cause a higher production of volatile phenols. Since this could not be observed in all cases, additional factors, for example phenolic inhibitors, might be involved in triggering or suppressing that mechanism. The antimicrobial activity through an addition of lysozyme to wine fermentations, however, is accompanied by a side activity that needs to be considered from a stylistic perspective.

Acknowledgments: The project was partially supported by the German Ministry of Economics and Technology (via AiF) and the FEI (Forschungskreis der Ernährungsindustrie e.V., Bonn). Project AiF 15833 N.

Author Contributions: Stephan Sommer and Ulrich Fischer conceived and designed the experiments; Stephan Sommer and Pascal Wegmann-Herr performed the experiments; Stephan Sommer and Michael Wacker analyzed the data; Stephan Sommer wrote the paper.

Conflicts of Interest: The authors declare no conflict of interest. 


\section{References}

1. Radler, F. Microbiological principles of acid degradation in wine. In Zentralblatt fuer Bakteriologie, Parasitenkunde und Infektionskrankheiten, Abteilung II; Verlag von Gustav Fischer: Hamburg, Germany, 1966; Volume 120, pp. 237-287.

2. Toit, M.D.; Pretorius, I.S. Microbial spoilage and preservation of wine: Using weapons from nature's own arsenal-A review. S. Afr. J. Enol. Vitic. 2000, 21, 74-96.

3. International Organisation of Vine and Wine (OIV). Coei-1-lysozy: 2007: Lysozyme muramidase. In International CEnological Codex; International Organisation of Vine and Wine: Paris, France, 2007.

4. Weiand, J. Gärstörung: Bakterienkontrolle durch lysozym. Das Deutsch. Weinmag. 2004, 22, 24.

5. Gerbaux, V.; Villa, A.; Monamy, C.; Bertrand, A. Use of lysozyme to inhibit malolactic fermentation and to stabilize wine after malolactic fermentation. Am. J. Enol. Vitic. 1997, 48, 49-54.

6. Shugar, D. The measurement of lysozyme activity and the ultra-violet inactivation of lysozyme. Biochim. Biophys. Acta 1952, 8, 302-309. [CrossRef]

7. Couto, J.A.; Campos, F.M.; Figueiredo, A.R.; Hogg, T.A. Ability of lactic acid bacteria to produce volatile phenols. Am. J. Enol. Vitic. 2006, 57, 166-171.

8. Okamura, S.; Watanabe, M. Determination of phenolic cinnamates in white wine and their effect on wine quality. Agric. Biol. Chem. 1981, 45, 2063-2070.

9. Reguant, C.; Bordons, A.; Arola, L.; Rozes, N. Influence of phenolic compounds on the physiology of oenococcus oeni from wine. J. Appl. Microbiol. 2000, 88, 1065-1071. [CrossRef] [PubMed]

10. Suarez, R.; Suarez-Lepe, J.A.; Morata, A.; Calderon, F. The production of ethylphenols in wine by yeasts of the genera brettanomyces and dekkera: A review. Food Chem. 2007, 102, 10-21. [CrossRef]

11. Rapp, A.; Versini, G. Flüchtige phenolische verbindungen in wein. Deutsch. Lebensm.-Rundsch. 1996, 92, $42-48$.

12. Chatonnet, P.; Dubourdieu, D.; Boidron, J.N.; Lavigne, V. Synthesis of volatile phenols by saccharomyces cerevisiae in wines. J. Sci. Food Agric. 1993, 62, 191-202. [CrossRef]

13. Chatonnet, P.; Dubourdieu, D.; Boidron, J.N.; Pons, M. The origin of ethylphenols in wines. J. Sci. Food Agric. 1992, 60, 165-178. [CrossRef]

14. Dugelay, I.; Gunata, Z.; Sapis, J.C.; Baumes, R.; Bayonove, C. Role of cinnamoyl esterase activities from enzyme preparations on the formation of volatile phenols during winemaking. J. Agric. Food Chem. 1993, 41, 2092-2096. [CrossRef]

15. Grando, M.S.; Versini, G.; Nicolini, G.; Mattivi, F. Selective use of wine yeast strains having different volatile phenols production. Vitis 1993, 32, 43-50.

16. Sashiwa, H.; Saimoto, H.; Shigemasa, Y.; Ogawa, R.; Tokura, S. Lysozyme susceptibility of partially deacetylated chitin. Int. J. Biol. Macromol. 1990, 12, 295-296. [CrossRef]

17. Rebelein, H. Kolorimetrisches verfahren zur gleichzeitigen bestimmung der weinsäure und milchsäure in wein und most. Deutsch. Lebensm.-Rundsch. 1961, 57, 36-41.

18. Fernandes, E.N.; Reis, B.F. Automatic spectrophotometric procedure for the determination of tartaric acid in wine employing multicommutation flow analysis process. Anal. Chim. Acta 2006, 557, 380-386. [CrossRef]

19. Rentzsch, M.; Weber, F.; Durner, D.; Fischer, U.; Winterhalter, P. Variation of pyranoanthocyanins in red wines of different varieties and vintages and the impact of pinotin a addition on their color parameters. Eur. Food Res. Technol. 2009, 229, 689-696. [CrossRef]

20. Somers, T.C.; Verette, E.; Pocock, K. Hydroxycinnamate esters of vitis vinifera: Changes during white vinification, and effects of exogenous enzymic hydrolysis. J. Sci. Food Agric. 1987, 40, 67-78. [CrossRef]

21. Ong, B.Y.; Nagel, C.W. High-pressure liquid chromatographic analysis of hydroxycinnamic acid-tartaric acid esters and their glucose esters in vitis vinifera. J. Chromatogr. 1978, 157, 345-355. [CrossRef]

22. Ritter, G. Die Bedeutung der Phenolischen Saft- und Weininhaltsstoffe Während der Verarbeitung von äpfeln, Speierling und Weißen Trauben. 1994. Available online: https://www.tib.eu/de/suchen/id/TIBKAT\% 3A183811992/Die-Bedeutung-der-phenolischen-Saft-und-Weininhaltsstoffe/ (accessed on 19 January 2018).

23. Maier, T.; Sanzenbacher, S.; Kammerer, D.R.; Berardini, N.; Conrad, J.; Beifuss, U.; Carle, R.; Schieber, A. Isolation of hydroxycinnamoyltartaric acids from grape pomace by high-speed counter-current chromatography. J. Chromatogr. A 2006, 1128, 61-67. [CrossRef] [PubMed] 
24. Chamkha, M.; Cathala, B.; Cheynier, V.; Douillard, R. Phenolic composition of champagnes from chardonnay and pinot noir vintages. J. Agric. Food Chem. 2003, 51, 3179-3184. [CrossRef] [PubMed]

25. Hutter, K.-J. Schnellbestimmungen zur tot-lebend-analyse von hefezellen. Brauwelt 1992, 132, $252-259$.

26. Hutter, K.-J.; Nitzsche, F. Untersuchungen über die alterung der bierhefen mit hilfe der flusszytometrischen analyse. Monatsschr. Brauwiss. 2002, 55, 196-199.

27. Gerbaux, V.; Briffox, C.; Dumont, A.; Krieger, S. Influence of inoculation with malolactic bacteria on volatile phenols in wines. Am. J. Enol. Vitic. 2009, 60, 233-235.

28. Bartowsky, E.J.; Costello, P.J.; Villa, A.; Henschke, P.A. The chemical and sensorial effects of lysozyme addition to red and white wines over six months' cellar storage. Aust. J. Grape Wine Res. 2004, 10, 143-150. [CrossRef]

29. Sonni, F.; Cejudo Bastante, M.J.; Chinnici, F.; Natali, N.; Riponi, C. Replacement of sulfur dioxide by lysozyme and oenological tannins during fermentation: Influence on volatile composition of white wines. J. Sci. Food Agric. 2009, 89, 688-696. [CrossRef]

30. Geny, L.; Darrieumerlou, A.; Doneche, B. Conjugated polyamines and hydroxycinnamic acids in grape berries during botrytis cinerea disease development: Differences between 'noble rot' and 'grey mould'. Aust. J. Grape Wine Res. 2003, 9, 102-106. [CrossRef]

31. Cheynier, V.F.; Trousdale, E.K.; Singleton, V.L.; Salgues, M.J.; Wylde, R. Characterization of 2-S-glutathionyl caftaric acid and its hydrolysis in relation to grape wines. J. Agric. Food Chem. 1986, 34, 217-221. [CrossRef]

32. Singleton, V.; Salgues, M.; Zaya, J.; Trousdale, E. Caftaric acid disappearance and conversion to products of enzymic oxidation in grape must and wine. Am. J. Enol. Vitic. 1985, 36, 50-56.

33. Cabrita, M.J.; Torres, M.; Palma, V.; Alves, E.; Patão, R.; Costa Freitas, A.M. Impact of malolactic fermentation on low molecular weight phenolic compounds. Talanta 2008, 74, 1281-1286. [CrossRef] [PubMed]

34. Knorr, D.; Shetty, K.J.; Kinsella, J.E. Enzymatic lysis of yeast cell walls. Biotechnol. Bioeng. 1979, 21, $2011-2021$. [CrossRef]

35. Walker, G.M. Yeast Physiology and Biotechnology; John Wiley \& Sons: West Sussex, UK, 2000.

36. Campos, F.M.; Couto, J.A.; Hogg, T.A. Influence of phenolic acids on growth and inactivation of oenococcus oeni and lactobacillus hilgardii. J. Appl. Microbiol. 2003, 94, 167-174. [CrossRef] [PubMed]

37. Chatonnet, P.; Barbe, C.; Canal-Llauberes, R.M.; Dubourdieu, D.; Boidron, J.N.; Pons, M. Incidence of some pectolytic preparations on the volatile phenols content of white wines. J. Int. Sci. Vigne Vin 1992. Available online: http:/ / agris.fao.org/agris-search/search.do?recordID=FR9304000 (accessed on 19 January 2018).

38. Molenaar, D.; Bosschner, J.S.; Brink, B.; Driessen, A.J.M. Generation of a proton motive force by histidine decarboxylation and electrogenic histidine/histamine antiport in lactobacillus buchneri. J. Bacteriol. 1993, 175, 2864-2870. [CrossRef] [PubMed]

(c) 2018 by the authors. Licensee MDPI, Basel, Switzerland. This article is an open access article distributed under the terms and conditions of the Creative Commons Attribution (CC BY) license (http://creativecommons.org/licenses/by/4.0/). 